\title{
ANALISIS PENGARUH BAURAN PEMASARAN TERHADAP KEPUTUSAN PEMBELIAN PRODUK HANDPHONE MEREK SAMSUNG DI YOGYAKARTA
}

\author{
Indria Dewi Taufiqiyah \\ Indria_dewitaufiqiyah@yahoo.co.id \\ Universitas Ahmad Dahlan \\ Hendro Setyono \\ hendro.setyono@yahoo.com \\ Universitas Ahmad Dahlan
}

\begin{abstract}
ABSTRAK
The purpose of this study is to determine whether the marketing mix of products, prices, distribution / place, and promotion influences the purchasing decision of Samsung brand mobile phone products. The sample used in this study amounted to 70 respondents, while the sampling method using purposive sampling. Data analysis method used is quantitative analysis with the validity and reliability tests, multiple linear regression, $t$ test, $F$ test, and the coefficient of determination. By using multiple methods it can be concluded that the product variable has a negative effect and is not significant to the purchase decision with a significance value ( $\mathrm{P}$ Value) of $0.831>0.05$. While the price variable has a positive and significant effect on purchasing decisions with a significance value of $0.002<0.05$, and the distribution / place variable has a positive and not significant effect on a purchase decision with a significance value of $0.058>0.05$, and the promotion variable has a positive and significant effect on a purchase decision with a significance value $0.001<0.05$. The resulting determination coefficient is 0.629 , which means that $62.9 \%$ of the change in the purchase decision variable is explained by the product, price, distribution / place and promotion variables together, while the remaining $37.1 \%$ is explained by other variables not included in this study.
\end{abstract}

Keyword: Product; Price; Distribution; Promotion; Purchase Decision.

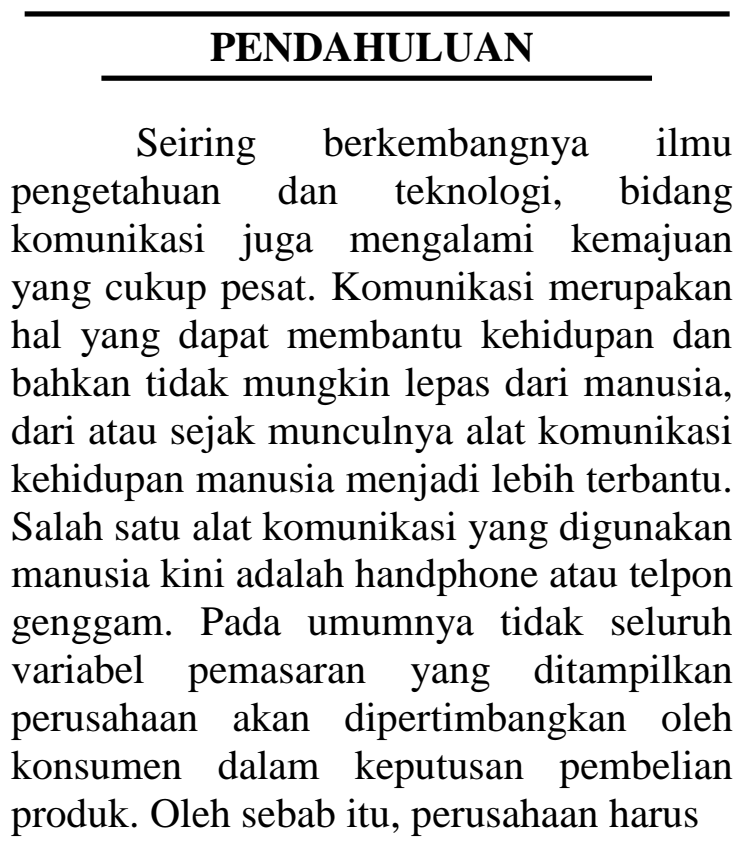

mengetahui variabel bauran pemasaran dan variabel paling dominan yang berpengaruh dalam mempertimbangkan pembelian suatu produk oleh konsumen. Dalam pemasaran selalu dihadapkan pada masalah produk, harga, distribusi dan promosi yaitu berapa dan bagaimana bauran pemasaran tersebut ditetapkan, agar tujuan perusahaan dapat tercapai dengan baik.

Selain itu, keputusan pembelian konsumen juga menjadi masalah lain yang sering timbul. Keputusan pembelian merupakan kegiatan individu yang secara langsung terlibat dalam pengambilan keputusan untuk melakukan pembelian terhadap produk yang ditawarkan oleh 
penjual

(http://www.zoeldhaninfomanajemen.com/2012/02/pengertiankeputusanpembelian.html). Para pembeli tersebut dipengaruhi oleh informasi tentang produk, harga, distribusi dan promosi, kemudian konsumen mengelola semua informasi tersebut dan mengambil kesimpulan berupa respon untuk membeli

\section{Rumusan Masalah}

1. Apakah produk berpengaruh terhadap keputusan pembelian produk handphone merek SAMSUNG

2. Apakah harga berpengaruh terhadap keputusan pembelian produk handphone merek SAMSUNG?

3. Apakah distribusi/tempat berpengaruh terhadap keputusan pembelian produk handphone merek SAMSUNG?

4. Apakah promosi berpengaruh terhadap keputusan pembelian produk handphone merek SAMSUNG?

\section{REVIEW LITERATUR DAN HIPOTESIS}

\section{Landasan Teori \\ Pengertian Pemasaran}

Menurut Kotler (2000), adalah suatu proses sosial yang didalamnya individu dan kelompok mendapatkan apa yang mereka butuhkan dan inginkan dengan menciptakan, menawarkan, dan secara bebas mempertukarkan produk yang bernilai dengan pihak lain.

\section{Manajemen Pemasaran}

Manajemen pemasaran yang dirumuskan American Marketing Association dalam buku (Kotler, Ang, Leong, dan Tan, 2000) adalah proses perencanaan dan pelaksanaan konsepsi, penentuan harga dan distribusi barang, jasa, dan gagasan untuk menciptakan pertukaran dengan kelompok sasaran yang memenuhi tujuan pelanggan dan organisasi.

\section{Pengertian Bauran Pemasaran}

Menurut Kotler (2000), mendefinisikan bauran pemasaran adalah seperangkat alat pemasaran yang digunakan perusahaan untuk mencapai tujuan pemasaran di dalam pasar sasaran. Bauran pemasaran merupakan variabelvariabel terkendali yang dapat digunakan perusahaan untuk mempengaruhi konsumen dari segmen pasar tertentu yang dituju perusahaan.

Secara ringkas tiap-tiap variabel pemasaran di uraikan sebagai berikut :

\section{a. Produk (Produck)}

Menurut Kotler dan Armstrong (2001), produk adalah segala sesuatu yang dapat ditawarkan ke pasar untuk mendapatkan perhatian, dibeli, digunakan, atau dikonsumsi yang dapat memuaskan keinginan atau kebutuhan. Berdasarkan definisi diatas, maka produk didefinisikan sebagai kumpulan dari atribut-atribut yang nyata maupun tidak nyata, termasuk didalamnya kemasan, warna, harga, kualitas dan merek ditambah dengan jasa dan reputasi penjualanya.

\section{b. Harga (Price)}

Menurut Assauri (2004), harga merupakan suatu elemen bauran pemasaran yang menghasilkan penerimaan penjualan, sedangkan elemen-elemen lainya hanya menimbulkan biaya. Kerena menghasilkan penerimaan penjualan, maka harga mempengaruhi tingkat penjualan, tingkat keuntungan yang di dapat oleh perusahaan.

\section{c. Distribusi/Tempat (Place)}

Tempat mencerminkan kegiatankegiatan perusahaan yang membuat produk tersedia untuk konsumen sasaran. Sebagian dari tugas distribusi adalah memilih perantara yang akan digunakan dalam saluran distribusi yang secara fisik menangani dan mengangkat produk melalui saluran tersebut, maksudnya agar produk dapat mencapai pasar yang dituju tepat pada waktunya.

\section{d. Promosi (Promotion)}

Menurut (Tjiptono 2008), pada hakikatnya promosi adalah suatu bentuk 
komunikasi pemasaran. Yang dimaksud komunikasi pemasaran adalah aktifitas pemasaran yang berusaha menyebarkan informasi, mempengaruhi/membujuk, dan atau mengingatkan pasar sasaran atas perusahaan dan produknya agar bersedia menerima, membeli dan loyal pada produk yang ditawarkan perusahaan yang bersangkutan.

\section{Keputusan Pembelian}

Menurut Schiffman dan Kanuk (2004), keputusan pembelian adalah pemilihan dari dua atau lebih alternatif pilihan keputusan pembelian, artinya bahwa seseorang dapat membuat keputusan, harus tersedia beberapa alternatif pilihan. Keputusan untuk membeli dapat mengarah pada bagaimana proses dalam pengambilan keputusan tersebut itu dilakukan. Keputusan pembelian konsumen dipengaruhi oleh perilaku konsumen.

\section{Penelitian Terdahulu}

1. Penelitian terdahulu dilakukan oleh Komalasari (2011). Variabel yang digunakan dalam penelitian ini adalah keputusan pembelian sebagai variabel dependen, sedangkan variabel independen yang digunakan adalah produk, harga, distribusi/tempat, dan promosi.

Berdasarkan uji analisis yang telah dilakukan maka dapat diambil kesimpulan bahwa:

a. Secara simultan bauran pemasaran yaitu produk, harga, distribusi/tempat dan promosi berpengaruh terhadap keputusan pembelian produk handphone Nokia Eseries.

b. Secara parsial dari empat variabel bauran pemasaran hanya dua variabel yang berpengaruh signifikan terhadap keputusan pembelian produk handphone Nokia Eseries, yaitu harga dan distribusi/tempat.

2. Penelitian kedua dilakukan oleh Sulistyawati (2010). Variabel yang digunakan dalam penelitian ini adalah citra merek dan kualitas produk,

Berdasarkan uji analisis yang telah dilakukan maka dapat diambil kesimpulan bahwa:

a. Pernyataan hipotesis pertama (H1) dapat diterima, maka citra merek berpengaruh positif dan signifikan terhadap keputusan pembelian konsumen. Kondisi tersebut dapat dilihat dari koefisien variabel citra merek yang bernilai 0,250, angka signifikansi sebesar 0,017 (kurang dari 0, 05).

b. Pernyataan hipotesis kedua (H2) dapat diterima, maka kualitas produk berpengaruh positif dan signifikan terhadap keputusan pembelian konsumen. Kondisi tersebut dapat dilihat dari koefisien variabel kualitas produk yang bernilai 0,559, angka signifikansi sebesar 0,000 (kurang dari 0,05).

\section{Hipotesis}

H1: Diduga ada pengaruh dari produk terhadap keputusan pembelian produk handphone merek SAMSUNG.

H2: Diduga ada pengaruh dari harga, terhadap keputusan pembelian produk handphone merek SAMSUNG.

H3: Diduga ada pengaruh dari distribusi/tempat terhadap keputusan pembelian produk handphone merek SAMSUNG.

H4: Diduga ada pengaruh dari promosi terhadap keputusan pembelian produk handphone merek SAMSUNG.

\section{METODE PENELITIAN \\ Populasi dan Sampel}

Populasi adalah wilayah generalisasi yang terdiri atas obyek/subyek yang mempunyai kualitas dan karakteristik tertentu yang ditetapkan oleh peneliti 
untuk dipelajari dan kemudian ditarik kesimpulannya (Sugiyono, 2008). Dalam penelitian ini, populasi adalah pengguna produk handphone merek SAMSUNG yang ada di Yogyakarta.

$$
\text { Menurut Sugiyono }
$$
menyatakan bahwa sampel adalah bagian dari jumlah dan karakteristik yang dimiliki oleh populasi tersebut. Bila populasi besar, dan peneliti tidak mungkin mempelajari semua yang ada pada populasi, misalnya karena keterbatasan dana, tenaga, waktu, maka peneliti dapat menggunakan sampel yang diambil dari populasi itu. Sampel pada penelitian diperoleh langsung dari para konsumen yang telah menggunakan produk handphone merek SAMSUNG yang ada di Yogyakarta.

\section{Definisi Operasional}

1. Variabel Independen

Variabel bebas adalah variabel yang dapat mempengaruhi perubahan dalam variabel dependen yang mempunyai hubungan positif ataupun negatif bagi variabel dependen nantinya.Variasi dalam variabel dependen merupakan hasil dari variabel independen.Adapun Variabel bebas dalam penelitian ini adalah produk, harga, distribusi/tempat, dan promosi.

2. Variabel Dependen

Variabel tidak bebas adalah variabel yang menjadi perhatian utama dalam sebuah pengamatan penelitian. Pengamatan akan dapat memprediksikan ataupun menerangkan variabel bahwasannya variabel dependen beserta perubahannya yang terjadi kemudian. Dalam penelitian ini variabel tidak bebas adalah keputusan pembelian.

\section{Uji Instrumen}

\section{Uji Validitas}

Validitas suatu alat ukur adalah apakah suatu alat ukur dapat mengukur apa yang sebenarnya ingin di ukur. Uji validitas perlu dilakukan untuk mengetahui sejauh mana suatu alat ukur yang digunakan dalam penelitian dapat mengukur apa yang sebenarnya ingin peneliti ukur atau dapat digunakan untuk menguji instrument penelitian agar instrument tersebut dapat memberikan hasil sesuai dengan tujuanya (Cooper dan Schindler, 2001 ).

Pengujian validitas yang dilakukan adalah construct validity dengan metode confirmatory factor analysis yang dilakukan dengan program SPSS. Analisis faktor digunakan dalam analisis penelitian ini karena merupakan salah satu metode statistik multivariate yang tujuan utamanya untuk meringkas atau mengurangi data atau variabel yang akan diperlukan untuk di analisis. Analisis faktor memecahkan masalah yang menyangkut hubungan timbal balik antara sejumlah indikator dan kemudian menjelaskan keterkaitan antar indikator ke dalam dimensi-dimensi yang mendasari hubungan tersebut. Dan karena item-item pertanyaan dalam kuisioner diadopsi dari penelitian sebelumnya dengan dimodifikasi maka analisis faktor yang dilakukan bersifat confirmatory, yaitu saat pengolahan pada tahap extraction dipilih number of factor adalah 5 sesuai dengan variabel yang diuji dalam model penelitian. Kriteria signifikansi terhadap item-item pertanyaan dalam penelitian ini didasarkan pada signifikansi praktis (practical significance) (Hair et al., 1998) seperti terlihat pada Tabel 3 berikut: 
Tabel 3.1

Signifikansi Faktor Loading

\begin{tabular}{|l|l|}
\hline \multicolumn{1}{|c|}{ Faktor Loading } & \multicolumn{1}{c|}{ Keterangan } \\
\hline Lebih besar dari 0.30 & Level minimal \\
\hline Lebih besar dari 0.40 & Sangat Penting \\
\hline Lebih besar dari 0.50 & Signifikan \\
\hline Sumber: Hair et al., 1998 & \\
\hline
\end{tabular}

Pedoman umum yang dipakai adalah semakin besar factor loading semakin penting indikator tersebut dalam menafsirkan suatu faktor (Hair et al., 1998). Item-item yang mempunyai factor loading kurang dari 0,40 akan dikeluarkan karena dianggap hanya mempunyai kemampuan menafsirkan suatu faktor pada level minimum. Sedangkan item yang mempunyai factor loading lebih besar dari 0,40 dianggap signifikan dan bisa dimasukkan sebagai anggota suatu faktor.

Dari hasil reliabilitas, dilakukan analisis faktor terhadap itemitem yang telah memenuhi nilai reliabilitas dengan memasukkan semua item tersebut dan kemudian mengeliminasi item tersebut satu per satu bagi item yang tidak memenuhi persyaratan seperti dijelaskan sebelumnya, yaitu memiliki lebih dari satu nilai loadings yang mirip pada beberapa faktor yang berbeda, memiliki nilai loading yang lebih besar pada faktor lain dibandingkan pada faktornya, atau tidak memiliki nilai loading pada faktornya.

2. Uji Reliabilitas

Uji reliabilitas untuk menguji ketepatan instrumen pengukur dengan konsistensi diantara butir-butir pernyataan dalam suatu instrumen. Reliabilitas berkaitan dengan ketepatan prosedur pengukuran dan konsistensi. Suatu alat ukur yang dinilai reliabel jika pengukur tersebut menunjukkan hasilhasil yang konsisten dari waktu ke waktu.
Peneliti menguji instrumen penelitian dengan sampel sejumlah 70 responden. Koefisien reliabilitas ditunjukkan oleh koefisien Cronbach Alpha yang berkisar antara 0 sampai 1 . Semakin tinggi nilai koefisien Cronbach Alpha berarti semakin tinggi reliabilitas alat ukur yang digunakan. Untuk menguji reliabilitas dalam penelitian ini adalah dengan membandingkan Cronbach Coefficient Alpha (r Alpha) pada hasil olahan SPSS Release 16.0 dengan Rule of Thumb/ Kesepakatan Umum dari koefisien alfa yaitu lebih besar dari 0,6 untuk penelitian eksploratori

\section{Teknik Analisis Data}

1. Analisis Regresi Berganda

Analisis regresi berganda digunakan untuk mengetahui seberapa besar pengaruh bauran pemasaran terhadap keputusan pembelian konsumen pada produk handphone merek SAMSUNG. Persamaan regresi linier berganda adalah

$\mathrm{Y}=\mathrm{a}+\mathrm{b} 1 \mathrm{X} 1+\mathrm{b} 2 \mathrm{X} 2+\mathrm{b} 3 \mathrm{X} 3+\mathrm{b} 4 \mathrm{X} 4$ $+\mathrm{e}$

Dimana:

$\mathrm{Y}=$ Keputusan pembelian

$\mathrm{a}=$ Konstanta

$\mathrm{X} 1=$ Produk

$\mathrm{X} 2$ = Harga

$\mathrm{X} 3=$ Tempat

$\mathrm{X} 4$ = Promosi

$\mathrm{E}=$ Error

\section{Uji Hipotesis}

\section{Uji Parsial (Uji T)}

Uji statistik $t$ pada dasarnya menunjukan seberapa jauh pengaruh satu variabel independen secara individual dalam menerangkan variabel dependen.

1). Dasar pengambilan keputusan (Ghozali, 2005) dilakukan dengan kriteria angka probabilitas signifikan sebagai berikut :

a. Jika probabilitas $\mathrm{t}>0$, 05, maka Ho diterima dan Ha ditolak 
b. Jika probabilitas $\mathrm{t}<0,05$, maka Ho di tolak dan Ha diterima.

2). Langkah-langkah analisis dalam pengujian hipotesis terhadap koefisien regresi adalah sebagai berikut (Algifari, 2003):

a. Perumusan Hipotesis :

Ho: $\beta 1: \beta 1: \beta 3: \beta 4=0$

Ha: $\beta 1: \beta 2: \beta 3: \beta 4=0$

b. Penentuan nilai kritis. Nilai kritis dalam pengujian hipotesis terhadap koefisien regresi dapat ditentukan dengan menggunakan tabel distribusi normal dengan memperhatikan tingkat signifikansi $(\alpha)$ dan banyaknya sampel yang digunakan. Misalnya untuk contoh kasus ini, tingkat signifikansi $(\alpha)$ yang digunakan $10 \%$. Karena pengujian ini dua sisi, maka penentuan ttabel menggunakan $\alpha 2$. (Lihat tabel distribusi $\mathrm{t}$ pada lampiran dengan ketentuan bahwa degree of freedom dan $\alpha=0,05$ ). c. Nilai ttest masing-masing koefisien regresi dapat diketahui dari hasil perhitungan computer.

d. Pengambilan keputusan dilakukan berdasarkan letak nilai ttest masingmasing koefisien regresi pada kurva normal yang digunakan dalam penentuan nilai kritis. Jika letak ttest suatu koefisien regresi daerah penerimaan $\mathrm{H} 0$ maka keputusanya adalah menerima H0. Artinya koefisien regresi tersebut tidak berbeda dengan nol. Atau dengan kata lain, variabel tersebut tidak berpengaruh terhadap suatu koefisien regresi ttest di daerah penolakan H0., maka keputusanya adalah menolak H0 dan menerima Ha. Artinya variabel independen tersebut tidak berpengaruh terhadap nilai variabel dependen. Atau dengan kata lain, variabel independen tersebut berpengaruh terhadap variabel dependen

e. Kesimpulan. Pada langkah keputusan dinyatakan menolak $\mathrm{H} 0$ dan $\mathrm{Ha}$. Artinya nilai koefisien regresi dari setiap persamaan regresi berbeda dengan 0. Sehingga dapat disimpulkan bahwa kedua variabel independen tersebut (X1, X2, X3, dan X4) berpengaruh terhadap variabel dependen (Y).

\section{Uji Simultan (Uji F)}

Uji $F$ digunakan untuk mengetahui tingkat signifikan pengaruh variabelvariabel independen secara bersamasama (simultan) terhadap variabel dependen (Ghozali, 2005).

a). Dalam penelitian ini, hipotesis yang digunakan adalah :

1. Apabila probabilitas signifikan > 0.05, maka H0 diterima dan Ha ditolak.

2. Apabila probabilitas signifikan < 0.05, maka H0 ditolak dan Ha diterima.

b). Langkah-langkah analisis dalam pengujian hipotesis terhadap variasi nilai variabel dependen yang dapat dijelaskan oleh variasi nilai variabel independen adalah sebagai berikut (Algifari, 2003):

1. Perumusan Hipotesis

H0: Variasi perubahan nilai variabel independen tidak dapat menjelaskan variasi perubahan nilai variabel dependen.

Ha: Variasi perubahan nilai variabel independen dapat menjelaskan variasi perubahan nilai variabel dependen.

2. Nilai kritis dalam distribusi $\mathrm{F}$ dengan tingkat signifikansi $(\alpha) 5 \%$ dan degree of freedom (D.F).

3. Nilai Ftest (lihat tabel ANOVA pada kolom F RATIO dari print out computer).

4. Kesimpulan. Pada langkah keputusan menolak $\mathrm{H} 0$ dan menerima $\mathrm{Ha}$, sehingga dapat disimpulkan bahwa variasi perubahan nilai variabel dependen dapat dijelaskan oleh variasi perubahan nilai semua variabel independen. Artinya, semua variabel independen (X1,X2,X3, dan X4) secara bersama-sama (secara simultan) dapat berpengaruh terhadap variabel dependen $(Y)$. 
3. Uji Koefisien Determinasi

Koefisien determinasi $\left(\mathrm{R}^{2}\right)$ pada intinya mengukur seberapa jauh kemampuan sebuah model menerangkan variasi variabel dependen (Ghozali, 2005).

\section{HASIL PENELITIAN DAN PEMBAHASAN}

\section{Hasil Penelitian}

1. Hasil Uji Validitas

Tabel 4.1

Hasil Uji Validitas

\begin{tabular}{|c|l|l|l|l|l|l|}
\hline \multirow{2}{*}{$\begin{array}{c}\text { Indikato } \\
\mathrm{r}\end{array}$} & \multicolumn{7}{|c|}{ Komponen } \\
\hline & 1 & 2 & 3 & 4 & 5 & \\
\hline $\mathrm{X} 1.1$ & 0.890 & & & & & Valid \\
\hline $\mathrm{X} 1.2$ & 0.892 & & & & & Valid \\
\hline $\mathrm{X} 1.3$ & 0.845 & & & & & Valid \\
\hline $\mathrm{X} 1.4$ & 0.911 & & & & & Valid \\
\hline $\mathrm{X} 2.1$ & & 0.820 & & & & Valid \\
\hline $\mathrm{X} 2.2$ & & 0.621 & & & & Valid \\
\hline $\mathrm{X} 2.3$ & & 0.859 & & & & Valid \\
\hline $\mathrm{X} 3.1$ & & & 0.861 & & & Valid \\
\hline $\mathrm{X} 3.2$ & & & 0.895 & & & Valid \\
\hline $\mathrm{X} 3.3$ & & & 0.855 & & & Valid \\
\hline $\mathrm{X} 4.1$ & & & & 0.722 & & Valid \\
\hline $\mathrm{X} 4.2$ & & & & 0.843 & & Valid \\
\hline $\mathrm{X} 4.3$ & & & & 0.736 & & Valid \\
\hline $\mathrm{X} 4.4$ & & & & 0.863 & & Valid \\
\hline Y1 & & & & & 0.863 & Valid \\
\hline Y2 & & & & & 0.683 & Valid \\
\hline Y3 & & & & & 0.865 & Valid \\
\hline Y4 & & & & & 0.688 & Valid \\
\hline Y6 & & & & & 0.783 & Valid \\
\hline Y8 & & & & & 0.862 & Valid \\
\hline Sumber: data primer diolah (2015) & & & \\
\hline
\end{tabular}

Dari tabel diatas dapat disimpulkan

bahwa dalam pengujian validitas, instrumen penelitian mencoba menguji terhadap 30 responden29 terlebih dahulu. Sedangkan dalam perhitungan, peneliti menggunakan program SPSS release 16.00 for windows.

a. Uji Validitas Variabel Produk (X1)

Tabel Component Matrix pada hasil output SPSS, terlihat terbentuk 1 component, artinya dari empat variabel yaitu X1.1, X1.2, X1.3, dan X1.4 dinyatakan valid dan hanya menjelaskan faktor produk.

b). Uji Validitas Variabel Harga (X2)

Tabel Component Matrix pada hasil output SPSS, terlihat bahwa hanya terbentuk 1 component, yang artinya dari tiga variabel yaitu X2.1, X2.2, dan X2.3 dinyatakan valid dan hanya menjelaskan faktor harga.

c). Uji Validitas Variabel Distribusi/tempat (X3)

Tabel Component Matrix pada hasil output SPSS, terlihat bahwa hanya terbentuk 1 component, yang artinya dari tiga variabel yaitu X3.1, X3.2, dan X3.3 dinyatakan valid dan hanya menjelaskan faktor distribusi/tempat.

d). Uji Validitas Variabel Promosi (X4)

Tabel Component Matrix pada hasil output SPSS, terlihat bahwa hanya terbentuk 1 component, yang artinya dari tiga variabel yaitu30 X4.1, X4.2, $\mathrm{X} 4.3$, dan X4.4 dinyatakan valid dan hanya menjelaskan faktor promosi.

e). Uji Validitas Variabel Keputusan (Y)

Tabel Component Matrix pada hasil output SPSS, terlihat bahwa terbentuk 2 component, padahal yang diharapkan hanya 1 komponen, yang artinya dari indikator Y1 sampai dengan Y8 ada yang tidak valid. Berarti proses harus di ulang dengan mengeluarkan indikator-indikator yang di anggap tidak valid.

2. Hasil Uji Reliabilitas

Tabel 4.2

Hasil Uji Realibilitas

\begin{tabular}{|l|l|l|l|}
\hline \multicolumn{1}{|c|}{ Variabel } & \multicolumn{1}{|c|}{$\begin{array}{c}\text { Cronbach's } \\
\text { Alpha }\end{array}$} & \multicolumn{1}{|c|}{ Nilai Kritis } & \multicolumn{1}{|c|}{ Keterangan } \\
\hline Produk (X1) & 0.907 & 0.60 & Reliabel \\
\hline Harga (X2) & 0.607 & 0.60 & Reliabel \\
\hline Tempat (X3) & 0.836 & 0.60 & Reliabel \\
\hline Promosi (X4) & 0.790 & 0.60 & Reliabel \\
\hline $\begin{array}{l}\text { Keputusan } \\
\text { Pembelian (Y) }\end{array}$ & 0.870 & 0.60 & Reliabel \\
\hline
\end{tabular}

Dari tabel reliabilitas diatas dapat dijelaskan bahwa tabel X1 indikator memiliki nilai Cronbach's Alpha 0.907 
yaitu lebih besar dari 0.60 berdasarkan ketentuan diatas maka indikatorindikator dalam variabel X1 dikatakan reliabel, selanjutnya variabel X2 indikator memiliki nilai Cronbach's Alpha 0.607 yaitu lebih besar dari 0.60 maka dinyatakan reliabel, selanjutnya variabel X3 dengan Cronbach's Alpha32 0.836 yaitu lebih besar dari 0.60 dinyatakan reliabel, dan variabel X4 memiliki nilai Cronbach's Alpha 0.790 lebih besar dari 0.60 dinyatakan reliabel, sedangkan variabel Y memiliki nilai Cronbach's Alpha 0.870 lebih besar dari 0.60, artinya dari kelima variabel baik dependen maupun independen semuanya dinyatakan reliabel dan layak untuk digunakan menjadi alat ukur kuesioner dalam penelitian ini.

3. Hasil Uji Regresi Linier Berganda Tabel 4.3

Hasil Uji Regresi ( Koefisien Regresi )

\begin{tabular}{|c|c|c|c|c|c|}
\hline & \multicolumn{2}{|c|}{$\begin{array}{c}\text { Unstandardized } \\
\text { Coefficients }\end{array}$} & $\begin{array}{c}\text { Standardized } \\
\text { Coefficients }\end{array}$ & & \\
\cline { 2 - 4 } Model & $\mathrm{B}$ & Std. Error & Beta & $\mathrm{T}$ & Sig \\
\hline 1 (constant) & $2.111 \mathrm{E}-16$ & .102 & & .000 & 1.000 \\
Produk & -.024 & .108 & -.024 & -.224 & .823 \\
Harga & .337 & .104 & .337 & 3.243 & .002 \\
Tempat & .200 & .104 & .200 & 1.926 & .058 \\
Promosi & .379 & .108 & .379 & 3.527 & .001 \\
& & & & & \\
\hline
\end{tabular}

Berdasarkan analisis data diatas diperoleh persamaan berikut :

$\mathrm{Y}=2.111 \mathrm{E}-16+-0.024 \mathrm{X} 1+0.337 \mathrm{X} 2$ $+0.200 \mathrm{X} 3+0.379 \mathrm{X} 4+\mathrm{e}$

Dari hasil persamaan regresi linier berganda tersebut, dapat diinterpresikan sebagai berikut:

$\mathrm{a}=2.111 \mathrm{E}-16$ merupakan nilai konstanta, jika nilai X1, X2, X3, dan X4 dianggap 0 maka akan menurunkan nilai keputusan pembelian sebesar 0.000

$b_{1}=-0.024$ artinya variabel produk berpengaruh negatif terhadap keputusan pembelian dan apabila variabel produk meningkat 1 satuan, maka nilai produk akan berpengaruh negatif dengan nilai 0.024. Seberapa tinggi kenaikan produk tidak akan mempengaruhi peningkatan keputusan pembelian.

$\mathrm{b}_{2}=0.337$ artinya variabel harga berpengaruh positif terhadap keputusan pembelian dan apabila variabel harga meningkat 1 satuan, maka nilai harga akan meningkat 0.337. Semakin tinggi kenaikan harga maka semakin tinggi pula pengaruh peningkatan keputusan pembelian.

$\mathrm{b}_{3}=0.200 \quad$ artinya variabel distribusi/tempat berpengaruh positif terhadap keputusan pembelian dan apabila variabel distribusi/tempat meningkat 1 satuan, maka nilai distribusi/tempat akan meningkat 0.200. Semakin tinggi kenaikan distribusi/tempat maka semakin tinggi pula pengaruh peningkatan keputusan pembelian.

$\mathrm{b}_{4}=0.379$ artinya variabel promosi berpengaruh positif terhadap keputusan pembelian dan apabila variabel promosi meningkat 1 satuan, maka nilai variabel promosi akan berpengaruh positif dengan nilai 0.379. Seberapa tinggi kenaikan variabel promosi akan mempengaruhi peningkatan keputusan pembelian.

4. Hasil Uji Parsial (Uji T)

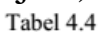

Tabel 4.4

Hasil Uji Signifikansi Parsial ( t )

\begin{tabular}{|c|c|}
\hline \multirow{2}{*}{ Variabel } & Hasil Uji \\
\cline { 2 - 2 } & Signifikansi \\
\hline Produk & 0.823 \\
\hline Harga & 0.002 \\
\hline Distribusi/tempat & 0.058 \\
\hline Promosi & 0.001 \\
\hline Sumber: Data primer, diolah (2015)
\end{tabular}

a. Variabel Produk

Hasil pengujian dengan SPSS untuk variabel produk diperoleh nilai $\mathrm{t}$ hitung $=-0.224$ tingkat signifikansi 0.823 dengan menggunakan batas signifikansi $(\alpha)=0.05$ maka nilai batas signifikansi $\alpha(0.05)<0.823$ maka hipotesis ditolak. Hal ini berarti produk 
(X1) tidak mempunyai pengaruh terhadap keputusan pembelian (Y), dikarenakan nilai signifikansi lebih besar dari $(\alpha)$.

\section{b. Variabel Harga}

Hasil pengujian dengan SPSS untuk variabel harga diperoleh nilai $t$ hitung $=3.234$ tingkat signifikansi 0.002 dengan menggunakan batas signifikansi $(\alpha)=0.05$ maka nilai batas signifikansi $\alpha(0.05)>0.002$ maka hipotesis diterima. Hal ini berarti harga (X2) mempunyai pengaruh terhadap keputusan pembelian (Y).

c. Variabel Distribusi/Tempat

Hasil pengujian dengan SPSS untuk variabel distribusi/tempat diperoleh nilai $\mathrm{t}$ hitung $=1.926$ tingkat signifikansi 0.058 dengan menggunakan batas signifikansi $(\alpha)$ $=0.05$ maka nilai batas signifikansi $\alpha$ $(0.05)<0.058$ maka hipotesis ditolak. Hal ini berarti Distribusi/tempat (X3) tidak mempunyai pengaruh terhadap keputusan pembelian (Y), dikarenakan nilai signifikansi lebih besar dari $(\alpha)$.

\section{d.Variabel Promosi}

Hasil pengujian dengan SPSS untuk variabel promosi diperoleh nilai $\mathrm{t}$ hitung $=3.527$ tingkat signifikansi 0.001 dengan menggunakan batas signifikansi $(\alpha)$ $=0.05$ maka nilai batas signifikansi $\alpha$ $(0.05)>0.001$ maka hipotesis diterima. Hal ini berarti Promosi (X4) mempunyai pengaruh terhadap keputusan pembelian (Y).
5. Hasil Uji Simultan (Uji F)

$$
\text { Tabel } 4.5
$$

Hasil Uji Simultan ( Uji F )

\begin{tabular}{|c|c|c|c|c|c|}
\hline Model & $\begin{array}{c}\text { Sum of } \\
\text { Squares }\end{array}$ & Df & Mean & F & Sig \\
\hline 1 Regresion & 21.476 & 4 & 5.369 & 7.344 & $.000^{\mathrm{a}}$ \\
Residual & 47.524 & 65 & .371 & & \\
Total & 69.000 & 69 & & & \\
& & & & & \\
\hline \multicolumn{2}{|l}{ Sumber: Data primer, diolah (2015) }
\end{tabular}

Berdasarkan hasil uji simultan dari tabel diatas ditunjukan bahwa $\mathrm{F}$ hitung sebesar 7.344 dan pada uji $F$ diatas didapatkan dengan taraf signifikasi 0.05 ( $\operatorname{sig} \alpha 0.000<0.05)$ dapat disimpulkan bahwa produk (X1), harga (X2), distribusi/tempat (X3), dan promosi (X4), secara bersamasama memiliki pengaruh yang signifikan terhadap keputusan pembelian (Y).

6. Hasil Uji Koefisien Determinasi Tabel 4.6

Hasil uji regresi ( Koefisien Determinasi )

\begin{tabular}{|l|r|r|r|r|}
\hline \multicolumn{1}{|c|}{ Model } & \multicolumn{1}{c|}{$\mathrm{R}$} & R Square & \multicolumn{1}{c|}{$\begin{array}{c}\text { Adjusted R } \\
\text { Square }\end{array}$} & $\begin{array}{r}\text { Std. Error of } \\
\text { the Estimate }\end{array}$ \\
\hline 1 & $.558^{\mathrm{a}}$ & .311 & .629 & .85506222 \\
\hline
\end{tabular}

Pada tabel diatas dapat dilihat bahwa nilai Adjusted $\mathrm{R}^{2}$ adalah sebesar 0.629 . Hal ini dapat diartikan bahwa variabel independen Produk (X1), Harga (X2), Distribusi/tempat (X3), Promosi (X4), dapat menjelaskan variabel dependen yaitu Keputusan pembelian (Y) sebesar $62.9 \%$ sedangkan sisanya diterangkan oleh faktor lain yang tidak diteliti.

\section{Pembahasan}

Pernyataan hipotesis pertama bahwa produk berpengaruh negatif dan tidak signifikan terhadap keputusan pembelian. Hal ini ditunjukan dengan nilai signifikansi ( $\mathrm{P}$ Value) 0.831 yang jauh lebih besar dari pada 0.05 serta nilai koefisien regresi sebesar -0.024 dapat disimpulkan bahwa produk (X1) 
berpengaruh negativ dan tidak signifikan terhadap keputusan pembelian (Y).

Pernyataan hipotesis kedua bahwa harga berpengaruh positif dan signifikan terhadap keputusan pembelian. Hal ini terbukti dengan nilai signifikansi 0.002 yang jauh lebih kecil dari 0.05 serta nilai koefisien regresi

sebesar 0.337 .

Pernyataan hipotesis ketiga bahwa distribusi/tempat berpengaruh positif dan tidak signifikan terhadap keputusan pembelian. Hal ini ditunjukan dengan nilai signifikansi 0.058 yang jauh lebih besar dari 0.05 serta koefisien regresi sebesar 0.200.Sehingga dapat disimpulkan bahwa distribusi/tempat berpengaruh positif dan tidak signifikan terhadap keputusan pembelian.

Pernyataan hipotesis keempat bahwa promosi berpengaruh positif dan signifikan terhadap keputusan pembelian. Hal ini dibuktikan dengan nilai signifikansi 0.001 yang jauh lebih kecil dari 0.05 serta koefisien regresi sebesar 0.379. Sehingga disimpulkan bahwa promosi berpengaruh positif dan signifikan terhadap keputusan pembelian.

\section{KESIMPULAN DAN SARAN}

\section{Kesimpulan}

Berdasarkan hasil analisis dan pembahasan, dapat ditarik kesimpulan sebagai berikut:

1. Secara parsial variabel produk tidak berpengaruh terhadap keputusan pembelian produk handphone merek SAMSUNG.

2. Secara parsial variabel harga berpengaruh terhadap keputusan pembelian produk handphone merek SAMSUNG.

3. Secara parsial variabel distribusi/tempat tidak berpengaruh terhadap keputusan pembelian produk handphone merek SAMSUNG.

4. Secara parsial variabel promosi berpengaruh terhadap keputusan pembelian produk handphone merek SAMSUNG.

5. Secara simultan bauran pemasaran yaitu produk, harga, distribusi/tempat dan promosi berpengaruh terhadap keputusan pembelian produk handphone merek SAMSUNG di Yogyakarta.

\section{Saran}

Dari hasil pembahasan dan kesimpulan yang telah dapat, maka diajukan saran sebagai berikut:

1. Kepada pihak perusahaan

Peneliti menyarankan agar perusahaan meningkatkan kualitas produk dan mempertimbangkan harga yang kompetitif untuk konsumen, dengan lebih menginovasikan produk-produk yang akan dipasarkan dengan menambah berbagai macam inovasi, fitur maupun aplikasi yang lebih canggih, sehingga dapat menarik konsumen lebih banyak untuk membelinya. Selain itu pelayanan serta keandalan dalam melakukan strategi pemasaran pelanggan juga harus ditingkatkan agar dapat mengahasilkan loyalitas dengan memberikan promosi produk agar konsumen tertarik dan untuk meningkatkan pangsa pasar yang lebih besar.

2. Bagi peneliti yang akan datang

a). Sebaiknya menggunakan sampel yang lebih banyak agar mendapatkan hasil yang lebih akurat.

b). Diharapkan penelitian ini dapat menjadi acuan bagi peneliti yang akan datang agar dapat memberikan gambaran tentang pengaruh bauran pemasaran terhadap keputusan pembelian.

\section{DAFTAR PUSTAKA}

Assauri, S. 2004. Manajemen Produksi dan Operasi. FEUI. Jakarta. 
Algifari. 2003. Statistika Deskriptif Plus. Yogyakarta: Unit Penerbit dan Percetakan.

Cooper, DR., \& Schindler, PS. 2001. Bussines Research Methods. 9th ed. Boston: Mc Graw Hill Book Co.

Doyle, Peter and John Saunders. 1995. "The Lead Of Marketing Decision."Jurnal Of Marketing Research". Edition 22th (February), P.54-65.

Ghozali, Imam. 2005. Aplikasi Analisis Multivariate dengan Program SPSS. Semarang: Badan Penerbit Universitas Diponegoro.

Hair, Joseph F., JR., Rolp E Adreson, Ronald L, Tatham and, William L Black. 1998. Multivariate Data Analysis. 5th ed. USA: Prentice Hall International, Inc.

Indrianto, Nur dan Supomo, Bambang. 2002. Metodologi Penelitian Bisnis. Yogyakarta: BPFE.

Jho, Mulya. 11 Mei 2014. "Pengertian dan Definisi Produk"[Online]. $<$ http://www.Mulya

Jho.Blogspot.com/2014/05/pengertia n dan definisi produk. 22 Juni 2015.

Komalasari, Fitri. 2011. Pengaruh Bauran Pemasaran Terhadap Keputusan Pembelian Produk Handphone Nokia Eseries. Jurnal Pemasaran. Depok: Fakultas Ekonomi Universitas Gunadarma.

Kotler, Philip. 2000. Manajemen Pemasaran. Edisi Melenium. Jilid 1. Jakarta: PT. Prenhallindo.

Kotler, Philip. 2000. Manajemen Pemasaran. Jilid 2. Jakarta: Bumi Aksara.
Kotler, Ang, Leong, dan Tan. 2000. Manajemen Pemasaran Perspektif Asia. Jilid 1. Yogyakarta: Andi Yogyakarta.

Kotler, Philip dan Gary Armstong. 2001. Prinsip-Prinsip Pemasaran. Jilid 1. Jakarta: Erlangga.

Kotler, dan Keller. 2009. Manajemen Pemasaran. Edisi Tiga Belas Jilid 1. Jakarta: Erlangga.

Peter. Paul J. Dan Jerry C. Olson. 2000. Perilaku Konsumen dan Strategi Pemasaran. Erlangga. Jakarta.

Sugiyono. 2004. Metode Penelitian Bisnis. Bandung: CV. Alfabeta.

Sugiyono. 2008. Metode Penelitian Bisnis. Bandung: Alfabeta.

Sulistiowati, Praba. Analisis Pengaruh Citra Merek dan Kualitas Produk Terhadap Keputusan Pembelian Laptop Merek Acer di Semarang. Jurnal Fix. Semarang : Universitas Diponegoro.

Schiffman, I.G. dan Leslie L.K. 2004. Consumer Behaviour. Edition. Prentice Hall. New Jersey.

Raden, Zoeldhan. 12 Februari 2012. "Pengertian Keputusan Pembelian" [Online]. <http://www.zoeldhan.Infomanajem en.com/2012/02/pengertiankeputusa n-pembelian.html. 23 Maret 2015.

Tjiptono,Fandy. 2001. Strategi Pemasaran. Penerbit ANDI. Yogyakarta.

Tjiptono, Fandy.2008. Strategi Pemasaran, Edisi ke 3.Yogyakarta:Andi. 